\title{
Withholding artificial nutrition and hydration
}

This special issue, Withholding artificial nutrition and hydration, comprises several papers, commentaries and responses centred largely around the issues raised by the 2011 decision of the English Court of Protection in $W v M{ }^{i}$ In that case, the mother of an adult patient applied for the withdrawal of life-sustaining treatment (specifically, artificial nutrition and hydration). In 2003, the patient, M, had contracted viral encephalitis and suffered irreparable brain damage as a result. She fell into a coma, and when she emerged appeared to be in a vegetative state and for 8 years was entirely dependent on lifesustaining care.

Following her mother's application, $\mathrm{M}$ was held to lack capacity and hence in accordance with section 4 of the Mental Capacity Act 2005 (MCA), the matter turned on whether it was in her best interests for the treatment to be withdrawn. It was made clear in the 1993 decision of Airedale NHS Trust $v$ Bland that lifesustaining treatment could be withdrawn from a patient in a permanent vegetative state (PVS) if, on balance, it was not in his or her interest to continue treatment. ${ }^{\text {ii }}$ The MCA also allows for withdrawal of treatment, although the approach to best interests is slightly different. However, the case of $W v M$ is importantly different from the Bland case, because $\mathrm{M}$ was found not to be in a PVS, but instead was minimally conscious (MC). Much evidence was presented of her capacity to respond to stimuli, seemingly express emotion and occasionally speak.

In the first of his papers in this issue (see page 543, Editor's choice), Julian Sheather provides an overview of the case, particularly illuminating the discussions of M's interests and the views of her carers and relatives about her prior wishes. In her paper (see page 559), W $v$ M, Emily Jackson draws out the distinctions between the cases. Bland was considered to have 'no best interests of any kind', whereas in $W v M$, Baker $\mathrm{J}$ was of the view that while the pleasures of life ...

${ }^{\mathrm{i}}$ In Re M (Adult Patient) (Minimally Conscious State: Withdrawal of Treatment) [2011] EWHC 2443 (Fam); [2012] 1 W.L.R. 1653. Also cited as W $v M$ [2011] EWHC 2443 (Fam).

ii [1993] AC 789 . may appear smaller, that does not mean they can be disregarded'. In his view, M did experience positive sensations and so the situation was not the same as that in Bland. Jackson also explains the impact of the MCA (and the attendant Code of Practice) in the case, which requires a 'checklist' approach to best interests aimed at avoiding a purely external, objective determination of the patient's best interests. Rather, the patient's wishes, feelings and values are to be taken into account. However, as Jackson points out, Baker J gave some factors, particularly the principle of preservation of life and the positive experiences of $\mathrm{M}$ considerable weight, while her previously expressed views that she would not have wished to live a life dependent on others were considered less weighty. Jackson concludes that the case demonstrates the court's preference for preservation of life and its unwillingness to be swayed by anything less than an extremely clear (probably written) expression of one's wishes about withdrawal of care in such situations.

In his second paper (see page 547, Editor's choice), he then explores the 'particular question of whether the former wishes of a once-autonomous adult should be respected after the capacity to make decisions to realise those wishes is lost'. He teases apart the distinction between 'biological death' and 'personal death', a distinction he suggests is most stark in cases where the patient is in a vegetative state. The great challenge in these cases arises where the past desires of the 'former person' conflict with the current interests of the 'biological person'. Discussing Dworkin's critical and experiential interests approach, Sheather argues that in cases such as $W v M$ it cannot be a matter just of prioritising one over the other, as the question of sufficiency of evidence about past desires becomes a potentially vexing issue, as it did in that case. In his view, while being in an MC state may be abhorrent to most of us, people who are MC do have interests and the court's role is protect their experiential interests insofar as it can, and hence the justifications for shortening their lives must be strong. Ezio Di Nucci (see page 555) provides an excellent critical appraisal of the role the theory of 'past' and 'present' interests played in the decision, arguing that favouring one set of interests over another (even where the interests are those of the same person) can be seen as discriminatory. It is particularly interesting to read these two papers in conjunction with Joanne Gordon's exploration of the past interests aspect of the decision from the perspective of Speech Act Theory (see page 570), which she argues 'provides a powerful challenge to the assumption that a past statement represents an individual's mental state'.

Walter Glannon (see page 551) presents two criticisms of the decision in $W v M$, explaining first how the Court of Property conflated the best interests test and the principle of sanctity of life, and then arguing that based on the facts continued treatment was not in M's best interests, because the burdens of it outweighed the benefits. Particularly important is Glannon's point that the Court's decision, which emphasised the 'fatal consequence' of removing treatment as being based on the 'mistaken assumption that death always harms a person'. The correct approach, he argues, is to weigh the benefits and burdens of continuing treatment and into this weighting should come the previously expressed interests of the person who can no longer communicate her desires. Her opinion, which evidence suggested would have been a desire for care to be withdrawn, should have been the decisive factor, not sanctity of life. Alexandra Mullock takes a similar position in her paper (see page 553), arguing that 'When patients have made informal statements of wishes and views, which clearly-if not precisely-apply to their present situation, judges should not feel free to usurp such expressions of autonomy unless there are compelling reasons for so doing'. Mullock makes the further point that where there is little evidence that a life is reasonable or even tolerable, 'there can be no justification for usurping autonomy in order to maintain a life that seems unbearable from a critical interests perspective and intolerable from an experiential perspective'.

Carolyn Johnston brings a somewhat different, but no less fascinating, approach to the case (see page 562), exploring the value of a 'narrative approach', which focuses on making a decision about continuing treatment (or otherwise) that 'fits 
the themes and overall direction of the patient's life story' as a way to promote the patient's best interests. Richard Huxtable presents some very interesting discussion of the evidentiary challenges that arise in determining past interests in the context of the MCA's requirements for a valid advance directive to be found.

These explorations are fleshed out by Dominic Wilkinson and Julian Savulescu's examination of the MC state (see page 557), in which they offer some views on some of the morally relevant aspects of what minimal consciousness entails in terms of patient experience and autonomy.
On a related topic-end-of-life decisions for terminally ill children-Brierley et al offers some insights into decision-making at the end of life and the influence of familial views (particularly religious views) (see page 573). After an examination of 203 cases in which withdrawal or limitation of invasive care was recommended, he argues that we need to be concerned about cases in which 'deeply held belief in religion can lead to children being potentially subjected to burdensome care in expectation of 'miraculous' intervention' and that 'it is time to reconsider current ethical and legal structures and facilitate rapid default access to Court in such situations when the best interests of the child are compromised in expectation of the miraculous'. Mark Sheehan (see page 585), Julian Savulescu (see page 583), Charles Foster (see page 578), Gregory Bock (see page 579) and Steve Clark (see page 582) all offer some thoughts in response which, in addition to Kate McMahon-Parkes' paper (see page 587) on refusal of treatment in the ambulance, conclude this fascinating issue on how we do, and how we should, deal with the difficult questions that challenge us at the end of a loved one's life.

Competing interests None.

Provenance and peer review Commissioned internally peer reviewed. 